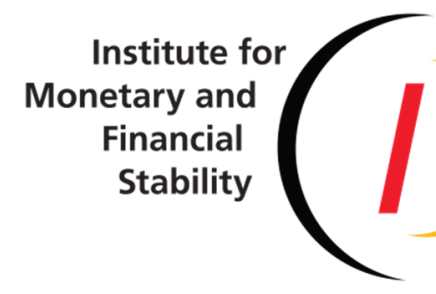

YVAN LENGWILER, ATHANASIOS ORPHANIDES

Collateral Framework:

Liquidity Premia and Multiple Equilibria

Institute for Monetary and Financial Stability

GOETHE UNIVERSITY FRANKFURT

WORKING PAPER SERIES NO. 157 (2021) 
This Working Paper is issued under the auspices of the Institute for Monetary and Financial Stability (IMFS). Any opinions expressed here are those of the author(s) and not those of the IMFS. Research disseminated by the IMFS may include views on policy, but the IMFS itself takes no institutional policy positions.

The IMFS aims at raising public awareness of the importance of monetary and financial stability. Its main objective is the implementation of the "Project Monetary and Financial Stability" that is supported by the Foundation of Monetary and Financial Stability. The foundation was established on January 1, 2002 by federal law. Its endowment funds come from the sale of 1 DM gold coins in 2001 that were issued at the occasion of the euro cash introduction in memory of the D-Mark.

The IMFS Working Papers often represent preliminary or incomplete work, circulated to encourage discussion and comment. Citation and use of such a paper should take account of its provisional character.

\section{Institute for Monetary and Financial Stability}

Goethe University Frankfurt

House of Finance

Theodor-W.-Adorno-Platz 3

D-60629 Frankfurt am Main

www.imfs-frankfurt.de | info@imfs-frankfurt.de 


\title{
Collateral Framework: Liquidity Premia and Multiple Equilibria*
}

\author{
Yvan Lengwiler and Athanasios Orphanides
}

April 2021

\begin{abstract}
Central banks normally accept debt of their own governments as collateral in liquidity operations without reservations. This gives rise to a valuable liquidity premium that reduces the cost of government finance. The ECB is an interesting exception in this respect. It relies on external assessments of the creditworthiness of its member states, such as credit ratings, to determine eligibility and the haircut it imposes on such debt. We show how such features in a central bank's collateral framework can give rise to cliff effects and multiple equilibria in bond yields and increase the vulnerability of governments to external shocks. This can potentially induce sovereign debt crises and defaults that would not otherwise arise.

Keywords: monetary policy, government finance, yields, liquidity premium, default premium, collateral, cliff effect, multiple equilibria.

JEL classification: E58, E62, E43.
\end{abstract}

*We thank Steven Cecchetti, Bill English, Hans Gersbach, Charles Goodhart, Robert King, Deborah Lucas, Kumar Rishabh, and Philip Turner for helpful discussions and comments. Correspondence: Lengwiler: University of Basel, Peter Merian-Weg 6, P.O. Box, CH-4002 Basel, Switzerland. Email: yvan.lengwiler@unibas.ch. Orphanides: MIT Sloan School of Management, E62-481, 100 Main Street, Cambridge, MA 02142, USA. Email: athanasios.orphanides@mit.edu. 


\section{Introduction}

The collateral framework of a central bank consists of the set of rules that determine what assets are eligible as collateral for securing liquidity from the central bank, and the terms of the associated credit operation. For any central bank, the collateral framework is a critical component of monetary policy strategy. A well-designed collateral framework can facilitate the smooth transmission of monetary policy and protect against financial vulnerabilities. Conversely, a poorly designed collateral framework can induce frictions and potentially cause a financial crisis.

Collateral frameworks vary across central banks, reflecting differences in institutions and the structure of the financial system across economies (BIS, 2013). One important commonality is that almost all central banks accept debt of their own governments without reservations. This makes government debt the most liquid asset in the economy, other than a central bank's own reserves, and gives rise to a valuable liquidity premium that reduces the cost of government finance. This favorable treatment of sovereign debt in a central bank's collateral framework is also a key reason why in advanced economies sovereign debt can enjoy the status of a "safe asset."

The ECB is an interesting exception in this respect. The ECB is the central bank of a monetary union serving multiple states, and its treatment of sovereign debt of its own governments is unique. It relies on external assessments of the creditworthiness of its member states, such as credit ratings, to determine the eligibility of government debt and the haircut it imposes on eligible debt. If sovereign debt has a high credit rating, the ECB accepts it as collateral without reservations and with negligible haircuts. With somewhat lower credit ratings, the ECB applies higher haircuts, reducing the liquidity premium. Below some credit rating threshold, the ECB considers sovereign debt ineligible as collateral for its monetary policy operations. ${ }^{1}$ The precise thresholds for eligibility and the haircuts applied on eligible assets reflect discretionary decisions of the ECB Governing Council. ${ }^{2}$

This unique feature of the treatment of sovereign debt in the ECB's collateral framework has attracted some attention since the Global Financial Crisis (GFC), in the context of tensions in euro area sovereign debt markets that have been unlike any experienced in

\footnotetext{
${ }^{1}$ The ECB introduced this eligibility condition for government debt in 2005. At the time, the threshold corresponded to an A credit rating (Orphanides, 2017). During the GFC, it was adjusted to BBB.

${ }^{2}$ The ECB's discretionary authority, which is far broader than that of peer central banks, arises from Article 18 of the Statute, see Lengwiler and Orphanides (2020).
} 
other advanced economies. ${ }^{3}$ Following the introduction of the euro in 1999 and until the GFC, euro area sovereign debt markets operated similarly to markets of other advanced economies. Monetary policy was smoothly transmitted in all member states of the euro area in a similar fashion through the term structure of sovereign debt. Changes in monetary policy were reflected in current and future expected interest rates (e.g. as summarized in the term structure of Overnight Indexed Swap (OIS) rates), and were transmited almost one-for-one to the term structure of sovereign debt, as in all other advanced economies. Spreads between sovereign yields and OIS were very small, as would be expected with a smooth monetary policy transmission process, and all these economies had well-functioning sovereign debt markets. Since the GFC, however, this has changed drastically. Figure 1 shows the spreads of government bond yields and the OIS rate at the two-year horizon for the euro area's four largest member states. Multiple episodes of spikes and reversals are visible, with disruptive changes in premia for some member states.

These spreads reflect numerous elements, importantly liquidity and potential default premia. Of course, liquidity and default premia may be interelated and, in equilibrium, may reflect fundamental economic factors as a well as the central bank's collateral framework.

In the case of the euro area, it has been argued that at least some of the observed changes in spreads since the GFC could not be attributed to economic fundamentals. ${ }^{4}$ Reflecting on his experience as ECB Vice President, Vitor Constâncio recounted that the sovereign debt tensions in the euro area could be interpreted as arising from a "demotion" of sovereign debt from the safe asset status it enjoyed before the GFC:

"The issue stems from the fact that the demotion of national public debt to debt with default risk opens the door, as in any other asset market, to episodes of acute liquidity stress with investors panicking or speculating, leading prices and yields to levels not justified by changes in fundamentals." (Constâncio, 2018)

In this paper, we explore the role of the central bank's collateral framework in determining government bond yields and spreads. As it relates to the ECB, this exploration can be useful in assessing whether aspects of the ECB's collateral framework may have played a role in the

\footnotetext{
${ }^{3}$ See e.g. European Parliament (2014), Gabor and Ban (2016) and Orphanides (2017, 2020). Bindseil, Corsi, Sahel, and Visser (2017) and Nyborg (2017) provide recent detailed descriptions of the ECB's collateral framework.

${ }^{4}$ De Grauwe and Yi (2013) and Bocola and Dovis (2019) provide pertinent empirical analysis.
} 
"demotion" of sovereign debt described by Constâncio (2018), inadverently stoking tensions and provoking concerns of default.

To this end, we first study the source of the liquidity premium in sovereign debt in a stylized general equilibrium banking model. In an environment where access to liquidity is valued, a more relaxed collateral policy induces a liquidity premium on government debt that depresses yields. Conversely, a more restrictive collateral policy that reduces the liquidity value of debt requires compensation in the form of higher yields, thus raising the cost of public finance.

We then introduce a cliff effect into the collateral framework to explore conditional eligibility: What are the implications of a collateral framework that considers sovereign debt to be eligible collateral if the economy's debt ratio falls below some threshold, but not eligible otherwise? Since, other things equal, higher debt ratios are associated with lower credit ratings and overall creditworthiness, this serves as a proxy for linking collateral elgibility to credit ratings. We show that such a contingent eligibility collateral status gives rise to multiple equilibria: A "bad" equilibrium with high yields and high debt (with no collateral eligibility) can coexist with a "good" equilibrium with low yields and a low level of government debt.

We further explore the implications of the collateral framework in a stochastic setting with possible default, when an adverse shock induces stress on public finances. In this setting, we find that a harsher treatment of government debt in the central bank's collateral framework makes the sovereign more vulnerable. A harsh collateral framework can induce a default when adverse shocks materialize, even when no default would have become necessary with a more lenient collateral framework. In effect, a harsh collateral treatment of government debt can become the cause of a sovereign debt crisis.

\section{The basic liquidity model}

The model features households who are the source of capital, and firms who require the capital to operate. The transfer of capital does not happen directly, but is mediated by banks. Banks collect the capital from the households by offering deposit contracts, and provide the capital to the firms through loan contracts. The model draws on the insights developed in the banking literature to justify the essential role of banks in the intermediation of credit, 
and the role of liquidity in this context (see, e.g. Diamond, 1984, Kashyap, Rajan, and Stein, 2002, Dang, Gorton, Holmström, and Ordoñez, 2017).

The yield that the bank receives from loans is higher than the interest it has to pay on deposits (assumed to be zero for simplicity). Alternatively, the bank can also invest in government bonds. Such bonds have the disadvantage that they (normally) yield less then loans, but the advantage that they are much more liquid.

The concept of liquidity that we use here is central to the model. We envision a situation where banks are in need of liquidating some of the deposits before the projects that have been financed with the loans are complete (in the spirit of Diamond and Dybvig, 1983). The banks will therefore have to come up with some form of liquidity to redeem the impatient depositors. In this model, the only source of cash to do this is the central bank that can lend liquidity in repo operations against collateral. This is where government bonds have an advantage. The central bank accepts safe government bonds as collateral with no additional charges and cost involved. The central bank would also accept loans as collateral, but this involves additional charges. Before accepting loans as collateral, their quality must be inspected, and this verification process is costly. Bonds allow the bank to avoid the transaction cost involved with pledging intransparent and illiquid loans as collateral.

Effectively, what we call loans in the model represents all kinds of bank assets that the central bank would potentially accept as collateral at worse terms than eligible collateral for monetary policy operations, e.g. emergency liquidity assistance (ELA).

The banks' problem boils down to the following trade-off: How much of the collected deposits should be invested in higher-yielding but less liquid loans, and how much should be invested in lower-yielding, but more liquid government bonds. This tradeoff gives rise to an arbitrage condition that relates the yield spread between loans and bonds to the level of transaction cost that can be avoided by holding bonds instead of loans. This spread is not a risk spread, but a liquidity spread.

\subsection{The banks' problem}

Households, firms, and banks act as price takers (there is a continuum of each class of agents). Time proceeds in three stages.

In stage 0 , households have an endowment $D$, which they deposit in the banks for safekeeping and to make daily transactions. The deposit rate is zero. Banks use this funding 
to provide capital $K$ in the form of loans to productive firms, in exchange for a (gross) loan rate $R$. Banks can also purchase government zero coupon bonds. Bonds cost $1 / r$ initially and return one unit in stage 2.

In stage 1 , a share $\lambda$ of households becomes impatient and withdraws their deposits and banks must redeem $\lambda D$ immediately. The only source of liquidity at that time is the central bank. The bank can pledge government bonds as collateral and receive liquidity from the central bank in a repo operation. The repo rate is again zero.

The central bank accepts the bonds as collateral at market value, but it can impose a haircut $h$ if it deems the bonds as not perfectly safe. Therefore, the bank can borrow $(1-h) B / r$ liquidity by pledging bonds with face value $B$ in a repo transaction.

If the bank does not have enough bonds to cover the need for liquidity, it can also pledge loans $K$. The central bank does provide liquidity against this collateral, but will inspect the quality of the collateral for a price of $\xi$, paid for by the bank. These costs are not a profit for the central bank but constitute resources the central bank needs to use to verify the appropriateness of the collateral.

Finally, in stage 2, loans, bonds, and repos mature, and banks return deposits to households.

Note that the assumptions of zero deposit and repo rates could easily be relaxed but they have no effect in this model, so we leave them aside to keep the model as simple as possible. Moreover, banks could also hold cash in their vault to accommodate the liquidity they will require in stage 1 . However, as long as the return rate on bonds is large enough, bonds dominate vault cash. The ability of banks to hold vault cash imposes a lower bound on the bond yield. As long as this lower bound is observed, banks would not willingly hold on to cash. We are not concerned with the difficulties of the lower bound in this paper, so we do not allow banks to hold vault cash in this model.

$$
\begin{aligned}
D & =K+\frac{B}{r}, \\
L & =\frac{(1-h) B}{r}, \\
V & =\xi \max \{0, \lambda D-L\}, \\
\pi & =R K+B-D-V .
\end{aligned}
$$
(available liquidity from repos) (cost of liquidity) (bank profit) 
$D$, the amount of endowments or initial deposits, is simply a scale for the model. There is no harm in assuming that $D=1$.

$L$ is the amount of liquidity banks can get by pledging government bonds as collateral in a repo with the central bank. Note that the marginal cost of liquidity depends on whether $L$ exceeds the need for liquidity $(\lambda D)$ or not. If a bank has sufficient bonds so that it can cover all its liquidity need with bonds, then it will not have to use the more costly form of collateral and the marginal cost of liquidity will be zero. In fact, in that case, bonds have no liquidity value at the margin and we should not expect a liquidity premium in equilibrium.

We will later impose an assumption that rules out this uninteresting case. For the moment, just assume that $\lambda D>L$. Substituting then yields the objective function of the banks

$$
\pi=R\left(D-\frac{B}{r}\right)+B-D-\xi\left(\lambda D-(1-h) \frac{B}{r}\right)
$$

The first-order condition (optimizing over $B$ ) then gives rise to an arbitrage condition

$$
r=R-(1-h) \xi
$$

This condition shows that bonds will enjoy a liquidity premium $(1-h) \xi$ over loans. The reason for this is that liquid assets are scarce: Banks are willing to accept a lower return by investing into bonds in exchange for marginally reducing the transaction cost $\xi$ they would incur to obtain liquidity from loans.

\subsection{General equilibrium}

Next, we introduce a role for public finance in production to close the model and study its general equilibrium properties. We choose to do this in a very simple manner. In effect, we posit that the government issues debt to finance the provision of public goods that serves as an input of production, together with private capital, which is financed by bank loans.

It is useful to describe the events of the three stages of the model again, but adding the behavior of firms and the government treasury that closes the model. The new parts are set in italics below.

In stage 0 , households have an endowment $D$, which they deposit in the banks for 
safekeeping and to make daily transactions. The deposit rate is zero. Banks use this funding to provide capital $K$ in the form of loans to productive firms, in exchange for a (gross) loans rate $R$. Banks can also purchase government zero coupon bonds. Bonds cost $1 / r$ initially and return one unit in stage 2. The government issues the bonds in order to finance public goods $G=B / r$. The public goods affect output $Y$ of the productive sector.

The intermediate stage 1 remains unchanged: a share $\lambda$ of households withdraws deposits, the banks acquire this liquidity with repo operations with the central bank, pledgling government bonds and, as a supplement, loans as collateral.

In stage 2, loans, bonds, and repos mature, and banks return deposits to households. Banks distribute their profits to the households, who are (implicitly) the owners of the banks. Firms do make not make profit due to constant returns to scale. Moreover, the government taxes households in order to be able to redeem the bonds.

Four additional equations describe the complete situation,

$$
\begin{aligned}
G & =\frac{B}{r}, \\
Y & =R^{\prime} K, \\
R^{\prime} & = \begin{cases}R>1 & \text { if } G \geqslant \gamma D, \\
1 & \text { otherwise }\end{cases} \\
\tau Y & =B .
\end{aligned}
$$
(production function) (productivity of capital) (taxation)

$G$ denotes the funds that the government collects by issuing bonds. The government produces some vital public goods that are needed for the private economy to operate: a judicial system, basic security, possibly some physical infrastructure, etc, essentially a functioning government. We assume here that the government finances these expenses by issuing debt. It will tax at the end of the game with a proportional income or consumption tax on the households.

The production function is particularly simple here. It exhibits constant marginal returns to provate capital $K$. This is the only factor that the firm controls, hence the firm operates under constant returns to scaling the inputs it controls. As a result, under competition, it makes no profit.

Furthermore, we assume that there is effectively no economic activity if public finance 
falls short of $\gamma D$. We can think of this amount of public activity as the cost of the mimimum necessary infrastructure that a private market economy requires. In that case, the return on private capital is $R>1$, capturing the value added that the firms create. If, however, the fundamental public goods are not provided, private production is not possible and firms are unable to produce added value $\left(R^{\prime}=1\right)$. The system reverts to autarky where households simply consume their endowment.

\subsection{Social welfare and scarcity of liquidity}

The private economy requires public goods in the amount $\gamma D$ that can only be provided by the state. Since providing more public goods than what is necessary would crowd out private investment, a natural benchmark is to focus on the minimal state, i.e. $B / r=\gamma D .^{5}$ The alternative is to have no state, $G=0$, and autarky, where households just consume their endowment.

In autarky, welfare is $W=D$. With a functioning state, welfare is the consumption that is made possible, net of the resources that are used to provide liquidity to the banks $V$,

$$
W:=Y-V= \begin{cases}R(1-\gamma) D-\xi(\lambda-(1-h) \gamma) D, & \text { if } G \geqslant \gamma D \\ D & \text { otherwise }\end{cases}
$$

In appendix A we establish the following sufficient condition for the private economy with the provision of the public good to be preferred to autarky,

Assumption 1 (private economy) $R(1-\gamma)>1+\xi \lambda$.

Since autarky removes everything that is potentially interesting in this model, we make this assumption. Furthermore, in the appendix we also establish that the bond supply will not be sufficient to cover the banks' liquidity requirement if the government is smaller than the share of early withdrawing depositors.

Assumption 2 (small state) $0<\gamma<\lambda<1$.

This assumption guarantees that liquidity is scarce in equilibrium $(\lambda D>L)$, so that bonds will enjoy a strictly positive liquidity premium. With this assumption, liquidity is valuable

\footnotetext{
${ }^{5}$ Issuing more bonds than necessary would provide more safe liquid assets for banks to use as collateral, but we show in appendix A that doing so strictly reduces welfare in this model.
} 
and a liquidity premium arises in equilibrium, leading to the the following result, ${ }^{6}$

Result 1 (liquidity premium) If assumptions 1 and 2 hold, the yield on government bonds is $r=R-(1-h) \xi$.

\subsection{Why does a haircut have a social cost?}

A restrictive collateral policy $(h>0)$ increases the yield on government bonds $r$. But welfare, according to (2), is independent of $r$. It does not matter how expensive the financing cost of the necessary public goods are, for two reasons: first, the amount of resources that are used for public goods is fixed in this model $(\gamma D)$ and is independent of $r$, so the amount of capital that is available to the private sector is independent of $r$ and therefore independent of $h$. Second, the financing cost $r$ of the government does indeed affect the extent of necessary taxation of households in stage 2, but a higher $r$ is also a source of income for banks who hold the bonds. Thus, a higher $r$ only results in a redistribution from households to banks, and if we assume that households own the banks, then there is not even a redistribution.

Turning to taxation, it is true that a larger haircut increases the need for taxation, and one could of course make an argument that taxing more heavily will create more deadweight loss. After all, all taxation is distortionary is practice. So this is one realistic source of welfare cost of haircuts. But we have ignored the welfare cost of taxation in this model, yet a haircut is still detrimental to welfare according to (2). Why is this so?

The reason is that a restrictive collateral policy has real resource cost in that it increases the banks' transaction cost of repos. A higher haircut makes the liquid asset more scarce, so that banks have to rely to a larger extent on using illiquid loans as collateral. But using loans for that purpose is socially costly because it requires the use of resources, what we have called "verification cost."

\section{Tough Love: Conditional eligibility}

The model of the previous section implies a straightforward connection between collateral policy $h$ and government bond yields $r$. A more restrictive collateral policy (positive $h$ ) simply reduces the liquidity value of the bonds, which manifests in a higher yield.

\footnotetext{
${ }^{6}$ This result together with assumption 1 implies a lower bound for the yield, $r>\frac{1-\xi(1-\gamma-\lambda)}{1-\gamma}$. This ensures that $r>0$, but it does not rule out $r<1$, i.e. depending on parameters, a negative interest rate on government debt is possible.
} 
But why would a central bank impose a haircut on government bonds? In the model, government bonds are by assumption free of default risk (we will come back to this assumption in sections 4). Of course, in practice, some (small) risk always pertains, so a central bank might want to over-protect its balance sheet from any actual or perceived credit risk. ${ }^{7}$

A common measure of solvency is the debt to GDP ratio. Other things equal, higher debt ratios are associated with lower overall creditworthiness, so we use the debt ratio in the model as a proxy for conditioning collateral elgibility to credit ratings in the simplest manner. We therefore examine the equilibrium outcomes when collateral eligibility is determined by comparing a sovereign's debt ratio to some threshold $\bar{\beta}$. Debt is eligible, with no haircuts, if the debt ratio is below the threshold and ineligible (i.e. $100 \%$ haircut) if the debt ratio exceed the threshold.

\subsection{The eligibility schedule and multiple equilibria}

The debt to GDP ratio in the model is given by $\beta:=B / Y ; B$ is the amount due in stage 2 and $Y$ is output. In particular, we assume that bonds are eligible as collateral for banks if and only if $\beta$ is below some threshold set by the central bank,

$$
h= \begin{cases}0 & \beta \leqslant \bar{\beta}, \\ 1 & \beta>\bar{\beta} .\end{cases}
$$

The bond is accepted with no haircut if the debt to GDP ratio is below the level acceptable to the central bank; it is not accepted otherwise. If the bond is eligible collateral it enjoys a liquidity premium (result 1), which helps keep the government debt abd deficit ratios low. If the bond is not considered eligible collateral by the central bank, the interest rate the government has to pay is high, which raises the deficit and debt ratios. This gives rise to multiple equilibria.

Result 2 (multiple equilibria) Let $\breve{\beta}$ be the debt to GDP ratio of the government if it can finance at the low rate $R=R-\xi$, and $\hat{\beta}$ be the corresponding ratio if it has to finance at the

\footnotetext{
${ }^{7}$ Note, however, that even if the collateral should fail, the balance sheet of the central bank is not directly at risk. The cost of the defaulting loan would be transferred to the borrowing bank. So, unless the borrowing bank also collapses, the central bank does not shoulder the loss.
} 
high rate $R$,

$$
\check{\beta}=\frac{\gamma}{1-\gamma} \cdot \frac{R-\xi}{R} \quad \text { and } \quad \hat{\beta}=\frac{\gamma}{1-\gamma}
$$

If $\check{\beta}<\bar{\beta}<\hat{\beta}$, the model has two equilibria (plus possibly a mixed one),

$$
\begin{aligned}
& h=0 \text { with } r=R-\xi \text { and } \beta=\check{\beta}, \quad \text { (good equilibrium) } \\
& h=1 \text { with } r=R \text { and } \beta=\hat{\beta} \text {. (bad equilibrium) }
\end{aligned}
$$

If $\hat{\beta}<\bar{\beta}$, only the good equilibrium exists; if $\bar{\beta}<\check{\beta}$, only the bad equilibrium exists.

Multiple equilibria occur if $\check{\beta}<\bar{\beta}<\hat{\beta}$. This case means that the government requires a sufficient spread on its debt compared to the loan rate in order to be able to produce a debt to GDP ratio that is deemed sufficiently low by the central bank to recognize the bonds as eligible collateral. If the spread (i.e. liquidity premium) is too small, the government cannot finance its operations and fulfill the central bank's maximum acceptable debt to GDP ratio.

The relationships that give rise to the multiple equilibria are captured by Figure 2 . If banks expect the central bank to accept the bond and impose no haircut, the interest rate will be low (top left quadrant), so that the government can finance its operations with relatively few bonds (bottom left quadrant). As a result, the debt to GDP ratio is $\check{\beta}<\bar{\beta}$ (top right quadrant) and the central bank indeed accepts the bonds as collateral. This is (1) in the figure. If, however, banks expect the bonds not to be eligible as collateral $(h=1)$, they are willing to purchase them only at a high interest rate. This implies that the government must sell many more bonds in order to be able to function and this causes the debt to GDP ration to exceed the limit set by the central bank, $\hat{\beta}>\bar{\beta}$, so that indeed the banks' expectation is fulfilled. This is (2) in the figure.

Figure 3 summarizes the resulting equilibria in $h-\beta$ space. The blue line traces the collateral policy, as a function of debt (reproduced from the top right quadrant of Figure 2). The green line shows the equlibrium relationship between the demand for bonds and the haircut, $h$, reflected in the top-left and bottom-left quadrants of Figure 2.

In the presence of the multiplicity induced by the cliff effect, the equilibrium that will obtain is purely belief driven. If the banks in stage 0 believe that the debt to GDP ratio will be smaller than the threshold set by the central bank $(\beta<\bar{\beta})$, they believe that the 
bonds will not be subject to a haircut $(h=0)$ and will be eligible collateral, and so they are willing to purchase the number of bonds that the government needs at a low yield $r=R-\xi$. Because of this low financing cost, the debt to GDP ratio will indeed satisfy the central bank's threshold, the central bank will accept the bonds as collateral, and the belief of the banks is vindicated.

If, however, the banks believe in stage 0 that the debt to GDP ratio will be unacceptable to the central bank in stage $1(\beta>\bar{\beta})$, then they also believe that the bonds will not be eligible collateral $(h=1)$. In that case, the price of the bonds settles on a high yield $r=R$, and then, indeed, the debt to GDP ratio of the government turns out to be high (due to the substantial interest burden), and the central bank does indeed not accept these bonds as collateral. As a result, the pessimistic expectation is again vindicated and we end up in the bad equilibrium.

The "bad equilibrium" is called bad here because it is worse in terms of welfare than the "good equilibrium," for the same reasons discussed in section 2.4. The fact that bonds are not eligible as collateral in the repo operations implies that more resources will have to be spent to vet collateral, which means that resources will be wasted in order for banks to receive the liquidity they require. If we also acknowledge that taxation is distortionary, the lack of a liquidity premium on bonds in the bad equilibrium increases the financing cost of the government, therefore increases the need for taxation, and therefore also increases the waste associated with taxation.

\subsection{Carrying over debt}

Our model is a one period model (with several stages). As such, strictly speaking, the world begins, the game plays out, and the world ends. Yet, it is of interest to draw implications that can capture an evolving debt dynamic. We do not model a repeated game, but we can add an element of this dynamic by introducing the notion of pre-existing debt. That is, posit that the government starts "the period" with some debt accumulated in the past. This debt needs to be rolled over, adding to the deficit that needs to be financed in the current period.

Let $B_{0}$ be existing bonds from previous periods. We can think of these bonds as bonds that mature and need to be rolled, or we can think of them as longer term bonds that do not currently mature. In either case, they contribute to the debt to GDP that is relevant for the decision of the central bank to accept the newly issued bonds as collateral. The debt to GDP 
ratio is now $\left(B_{0}+B\right) / Y$, or $\beta_{0}+\beta$, with $\beta_{0}:=B_{0} / Y$. The bonds are eligible as collateral if $\beta_{0}+\beta \leqslant \bar{\beta}$, which is equivalent to reducing $\bar{\beta}$ by $\beta_{0}$.

In other words, result 2 applies essentially unaltered. The limits of the regions are shifted, though,

$$
\check{\beta}=\frac{\gamma}{1-\gamma} \cdot \frac{R-\xi}{R}+\beta_{0} \quad \text { and } \quad \hat{\beta}=\frac{\gamma}{1-\gamma}+\beta_{0}
$$

A larger pre-existing debt can therefore move an economy from the "good equilibrium only" region to the "multiple equilibrium" region and further to the "bad equilibrium only" region.

Figure 4 provides a graphical illustation of this result. The central bank collateral policy, with threshold $\bar{\beta}$, may be set so that in the absence of any pre-exisising debt, there is no multiplicity of equilibria and only the "good" equilibrium is supported. This is the case (a) depicted in the figure that features only the good equilibrium (1). The same collateral policy, however, will give rise to a multiplicity if, for whatever reason, the government enters the period with a sufficiently high preexisting debt. This is case (b) in which both types of equilibria, (1) and (2), are possible. If the pre-existing debt is even larger, we enter case (c) in which the good equilibrium (1) is no longer valid.

This progression illustrates that the unintended conseqence of introducing a cliff effect in the central bank's collateral policy may not become apparent at the time when it is introduced, if debt ratios are initially fairly low. They can, however, become apparent following an adverse shock that raises the debt ratio in the economy, for example as materialized in virtually all advanced economies in the aftermath of the GFC.

\section{Equilibrium default}

Next, we turn our attention to the equilibrium relationship between liquidity and default premia with an illustrative example that shows how a harsh collateral treatment of government debt can reduce resilience to adverse shocks and induce default risk. To do so in the simplest possible manner, we return to the model in section 2 , where the collateral framework is described by a constant haircut, $h$, without a cliff effect.

The yield on government bonds is described by result 1 . The government has issued debt with face value $B$, and it will have to tax households by that amount. The household's income is $Y$, so the tax rate will be $\tau=B / Y$ (the debt or deficit to GDP ratio). 
In practise, there is a limit to the ability of the government to tax. For instance, it is obvious that the tax rate cannot be greater than $100 \%$. The true limit is very likely considerably lower. In fact, if $\tau R<1$, it would be better not to have a private economy and a government in the first place. We assume that the government cannot collect more than $\bar{\tau} Y$ tax revenue for some finite tax ceiling $\bar{\tau}$, and this value must be weighted against the need to redeem the bonds, $B$.

More precisely, if the required tax rate $\tau=B / Y$ exceeds the ability to tax $\bar{\tau}$, the government will not be in a position to fully redeem the maturing bonds, and it will have to partially default. This possibility introduces a default premium into the equilibrium yield on bonds, which itself increases the likelihood of default, as financing the operations of the government becomes more costly.

\subsection{Stochastic crisis and tax ceiling}

Assume that, with some small probability $p$, the economy faces a serious crisis in which some output $s D$ is lost. ${ }^{8}$ This shock occurs before the first leg of the repos have been initiated. More precisely, with some (small) probability $p$, the economy will be hit by a (large) shock $s$,

$$
\tilde{Y}=R K-\tilde{s} D, \quad \text { where } \quad \tilde{s}= \begin{cases}0 & \text { with probability } 1-p \\ s \quad \text { with probability } p\end{cases}
$$

We do not interpret the shock as a productivity shock in the firms. Firms' productivity is always $R$ and they produce and sell $R K$ goods. With probability $p$, however, $s D$ of the output "is lost." This is meant to capture a deterioration of the taxable base, due to a macroeconomic shock or crisis that can raise questions about debt sustainability. ${ }^{9}$

The maximum tax revenue is $\bar{\tau} \tilde{Y}$, and is therefore smaller if the crisis materializes. If the government cannot completely redeem the bond (i.e. $B>\bar{\tau} \tilde{Y}$ ), it will partially default. The recovery rate of the bond is given by

$$
\tilde{\delta}:=\min \left\{1, \frac{\bar{\tau} R K-\tilde{s} D}{B}\right\} .
$$

\footnotetext{
${ }^{8}$ The output shock is scaled with $D$ to keep everything in this model scaleable.

${ }^{9}$ The shock could just as well be modelled as a productivity shock. With random productivity $\tilde{R}$, the rate on loans would be $E[\tilde{R}]$, but nothing would fundamentally change.
} 
We denote the recovery rates conditional on no crisis with $\delta_{0}:=\left.\tilde{\delta}\right|_{\tilde{s}=0}$, and conditional on the crisis occurring as $\delta_{1}:=\left.\tilde{\delta}\right|_{\tilde{s}=s}$.

The sequence of events is as follows:

Stage 0: Households deposit their endowment with banks. Banks provide loans to firms and purchase bonds from the government.

Stage 1: The adverse output shock (4) materializes with probability $p$.

Stage 2: Some depositors withdraw. The first leg of the repos is made so that the banks can fulfill the withdrawals.

Stage 3: Households are taxed, all contracts resolve (the bonds are redeemed, loans are repaid, the second leg of the repos takes place, profit of the banks is distributed to the households), and output is sold to the households.

\subsection{Liquidity and risk premia}

Let $\tilde{\delta}:=\min \{1, \bar{\tau} \tilde{Y} / B\}$ be the recovery rate. The banks' profit function is then

$$
\tilde{\pi}=R K+\tilde{\delta} B-D-V
$$

We assume here that $B / r \geqslant \gamma D$ (the private economy works).

Banks choose $B$ to maximize expected profit. This yields a FOC and a modified arbitrage condition

$$
r=\frac{R-(1-h) \xi}{E[\tilde{\delta}]}
$$

assuming $B / r<\lambda D$ (the bank does not hold excess liquidity). This equation is the same as (1), with the addition of the expected recovery rate $E[\tilde{\delta}]$.

It is wothwhile to pause a little and ponder this equation. There are two effects that produce a wedge between the loan rate $R$ and the yield on government bonds. As before, bonds enjoy a liquidity premium $(1-h) \xi$ because they allow the banks a cheaper access to liquidity. In addition, however, there is a default premium $(1 / E[\tilde{\delta}])$ because the government might partially default on its bonds. Banks require this premium ascompensation for the expected less than perfect recovery rate. 


\subsection{Equilibrium}

The liability of the government is $B=r \gamma D$. The maximum tax receips are $\bar{\tau} Y=\bar{\tau}(R(1-$ $\gamma)-\tilde{s}) D$. Partial default $(\delta<1)$ happens if the former exceeds the latter,

$$
\tilde{\delta}=\min \left\{1, \frac{\bar{\tau} R(1-\gamma)-\tilde{s}}{r \gamma}\right\}
$$

with $r$ determined by (7). This is a fixed point problem because $\tilde{\delta}$ depends on $r$ and $r$ depends on $E[\tilde{\delta}]$. Let us get directly to the solution. The way to get to this solution is sligthly technical and provides little additional insight. This material is therefore relegated to an appendix.

\section{Result 3 (liquidity and default premium) Define}

$$
\check{s}:=\frac{R \bar{\tau}(1-\gamma)-\gamma(R-(1-h) \xi)}{\bar{\tau}} \text { and } \hat{s}=\frac{\check{s}}{p} \text {. }
$$

(a) If $s<\check{s}$, there is no default and $r=R-(1-h) \xi$.

(b) If $\check{s}<s<\hat{s}$, the equilibrium yield on government bonds is

$$
r=\frac{R-(1-h) \xi}{E[\tilde{\delta}]}
$$

where $E[\tilde{\delta}]:=\frac{(R-\xi(1-h))(1-p) \gamma}{(R-\xi(1-h)) \gamma-p \bar{\tau}(R(1-\gamma)-s)}$.

(c) If $\hat{s}<s$, the only equilibrium is autarky and a collapse of the state.

(d) Finally, note that

$$
\frac{\partial E[\tilde{\delta}]}{\partial h}<0, \quad \frac{\partial \check{s}}{\partial h}<0, \quad \text { and } \quad \frac{\partial \hat{s}}{\partial h}<0
$$

The proof is in appendix B. The result states that the depth of the crisis defines the qualitative properties of the equilibrium. If the crisis is benign $(s<\breve{s})$, the government is able to fully repay the debt even in crisis. Hence, the recovery rate is $100 \%$ and the equilibrium is not affected by the tax ceiling. If, on the other hand, the depth of the potential crisis is too large $(\hat{s}<s)$, the state cannot finance its operations and the economy reverts to autarky. The reason for this is that the possibility of the crisis state increases the interest the government 
has to pay on its debt, which can place them in trouble no matter what. There will be some default even if the crisis does not happen. The only equilibrium in that case is a collapse where the interest on bonds diverges to infinity and the government is not able to provide the public good that is necessary for the economy to function.

The intermediate case is the most interesting one. In that case $(\check{s}<s<\hat{s})$, government finances are fundamentally sound. Partial default occurs, however, if the economy is hit by a severe crisis. Thus, government bonds exist, but they are not perfectly safe, $E[\tilde{\delta}]<1$. The expected recovery rate $E[\tilde{\delta}]$ turns out to be increasing in $\bar{\tau}$. This implies that the default premium on the bond increases the more restrictive the tax ceiling of a country is (which is not surprising).

The collateral framework affects the quantitative feature of the intermediate case, and it affects the boundaries where the intermediate case is valid. First,

$$
\frac{\partial E[\tilde{\delta}]}{\partial h}<0
$$

means that a more restrictive collateral framework (larger $h$ ) decreases the expected recovery rate of government bonds. The yield on bonds therefore increases for two reasons: first, the liquidity premium of the bond decreases due to the direct effect of the reduced liquidity value that we know already from the basic model of section 2 . In addition, the reduced recovery rate of the bond pushes the yield on the bond further up still due to the higher default premium that the restrictive collateral framework induces.

Second,

$$
\frac{\partial \check{s}}{\partial h}<0 \text { and } \frac{\partial \hat{s}}{\partial h}<0
$$

means that a more restrictive collateral framework makes the government more vulnerable to smaller crises. If $h$ is small, the maximum crisis that the government can withstand without having to partially default (or without collapsing altogether) is greater; as $h$ increases, the ability of the government finances to withstand even medium sized crises is put into question.

Figure 5 illustrates the effect of the haircut in the equilibrium yield on government bonds. In this example, when the haircut is low, we are in case (a) of result 3 where there is no default. In this region, the haircut affects the liquidity premium only. As the haircut 
becomes more important, we enter case (b) and default will happen if the crisis materializes. As a result, a default premium is added to the yield as well.

In summary, quite different outcomes may obtain in the government bond market, including equilibria with and without risk of default. These outcomes correspond to alternative variations of the central bank's collateral framework and are not driven by differences in the intrinsic soundness of government finance.

\section{Fiscal discipline}

It is highly unusual for a central bank to set eligibility criteria for accepting debt of its own government as collateral for monetary policy operations. To our knowledge, the ECB is the only central bank that does. The ECB is in a special position, though, because it serves as the central bank of multiple countries and therefore deals with different issuers of public debt. When the monetary union was formed and the euro was introduced, the ECB accepted the government debt of all member states as eligible collateral without conditionality. Indeed, the government debt of all member states enjoyed the status of a safe asset, as had been agreed by the member states and incorporated in the European Union's Capital Requirement Directives (CRD) (Hannoun, 2011). ${ }^{10}$

Nonetheless, according to the Treaties, the ECB retained the discretionary authority to decide on its own what rules to apply for eligibility of any collateral, including government debt individual member states.

Using this authority, the ECB decided to change its collateral eligibility framework in 2005 in response to an agreement by governments to weaken the euro area's fiscal framework. ${ }^{11}$ This weakening generated concerns that in future euro area governments would be not be as fiscally disciplined as they had agreed to be when the euro was launched. ${ }^{12}$ Before the introduction of the euro, exchange rate risk was believed to serve this disciplining function. According to the ECB, since the euro eliminated exchange rate risk and associated interest rate premia, the fiscal discipline exerted by financial markets was blunted: "[t]he adoption of a common currency eliminates the exchange rate risk and the associated interest

\footnotetext{
${ }^{10}$ For example, according to the CRD, holdings of euro-denominated government debt of any euro area member state were not subject to exposures limits and were assigned a zero risk weight for the purposes of prudential regulation. (Directive 2006/48/EC of the European Parliament and of the Council of June 14 2006.)

${ }^{11}$ The weakening of the fiscal framework was documented by the ECB at the time (ECB, 2005).

${ }^{12}$ See Orphanides (2017) and references therein.
} 
rate risk premia among the participant countries, thus blunting the discipline normally exerted by financial markets on governments' fiscal behaviour." (ECB, 2005). While the euro area's original fiscal rules provided assurance that fiscal discipline could be maintained even in the absence of interest-rate premia due to exchange rate risk, once the fiscal rules were weakened the ECB assessed that another mechanism would be needed to enforce fiscal discipline. One available mechanism was the ECB's collateral framework, which the ECB could adjust unilaterally, using its discretionary authority.

The appropriateness of using the ECB's collateral framework as a disciplining device for its own governments is not obvious and was questioned even by members of the ECB Executive Board at the time:

"It has been recently argued that the ECB should use its collateral policy as a sanction to exert fiscal discipline [...] Although superficially appealing, this suggestion would be misguided. [...] it is clear that the design of the Stability and Growth Pact and its implementation are governmental responsibilities, to be controlled by parliaments. [...] it is not and cannot be the ECB's role to enforce fiscal discipline and to correct shortcomings in the implementation of the Stability and Growth Pact. Attempting to do so would politicise the ECB's operations and ultimately threaten its independence [... ]" (Issing, 2005).

Nonetheless, the ECB went ahead with the change in its collateral framework, adopting the use of credit rating thresholds for determining collateral eligibility of government debt. Whether the economic consequences of this change for euro area economies was sufficiently appreciated when this decision was made remains unclear.

\section{Conclusion}

A central bank's collateral framework is a critical part of its monetary policy strategy. The primary consideration in designing a central bank's collateral framework should be the smooth transmission of monetary policy. A well-designed collateral framework can also give rise to a valuable liquidity premium on government debt that reduces the cost of financing the provision of public goods and improves resilience to adverse shocks. This liquidity premium is greatest when the central bank accepts its own government's debt as collateral in credit operations without reservations. 
While almost all advanced economy central banks treat their governments' debt in this manner, the ECB is an interesting exception. The ECB has decided to use its discretionary authority to adopt a collateral framework that differentiates government debt of the economies it serves on the basis of external assessments of their perceived creditworthiness. Debt of governments with a lower perceived creditworthiness are subjected to higher haircuts in credit operations, which reduces their liquidity value and raises the cost of debt finance. Below some perceived creditworthiness threshold, government debt is declared ineligible and loses its liquidity value completely.

In this paper, we show that introducing external assessments and endogenous measures of perceived creditworthiness in this fashion has some potentially severe inadvertent sideeffects. First, this practice gives rise to undesirable cliff effects, which in turn can generate multiple equilibria: A good equilibrium with low debt and high perceived creditworthiness can coexist with a worse equilibrium (from a welfare perspective), with higher debt and lower perceived creditworthiness. Second, in a stochastic environment when an adverse shock to the economy can stress public finances, such a collateral framework can induce an otherwise unnecessary default. In effect, a harsh collateral treatment of government debt can make public finance more fragile than necessary and become the cause of a sovereign debt crisis.

These results reaffirm that central banks must be careful to avoid reliance on mechanistic approaches in their collateral frameworks that may compromise the liquidity value of government debt and reduce resilience to adverse shocks. Related concerns were acknowledged in the aftermath of the Global Financial Crisis, leading to calls for modification in central bank and regulatory practices (FSB, 2010). Recognition of the inadvertent sideeffects associated with the treatment of government debt in the ECB's collateral framework suggests this aspect of the ECB's policy strategy should be reexamined (Lengwiler and Orphanides, 2020).

From the central bank's perspective, liquidity and default premia are endogenous. They depend sensitively on the central bank's collateral framework. Safeguarding the liquidity value of government debt with a well-designed collateral framework is at the core of good central banking practice. 


\section{References}

Bindseil, Ulrich, Marco Corsi, Benjamin Sahel, and Ad Visser (2017). "The Eurosystem collateral framework explained." Occasional paper, no 189, European Central Bank. https://www. ecb. europa.eu/pub/pdf/scpops/ecb.op189.en.pdf.

BIS (2013). "Central Bank Collateral Frameworks and Practices." Report of a study group established by the markets committee, Bank for International Settlements. https://www . bis.org/publ/mktc06.htm.

Bocola, Luigi and Alessandro Dovis (2019). "Self-Fulfilling Debt Crises: A Quantitative Analysis." American Economic Review 109(12):4343-77. https://www. aeaweb.org/ articles?id=10 . 1257/aer . 20161471.

Constâncio, Vitor (2018). "Completing the Odyssean journey of the European monetary union." Speech at the ECB Colloquium on The Future of Central Banking. https: //www. ecb. europa.eu/press/key/date/2018/html/ecb.sp180517. en. html.

Dang, Tri Vi, Gary Gorton, Bengt Holmström, and Guillermo Ordoñez (2017). "Banks as Secret Keepers." American Economic Review 107(4):1005-1029. https : //doi . org/10 . 1257/aer. 20140782.

De Grauwe, Paul and Juemei Yi (2013). "Self-fulfilling crises in the Eurozone: An empirical test." Journal of International Money and Finance 34:15-36. https : //doi . org/10 . 1016/ j.jimonfin.2012.11.003.

Diamond, Douglas W. (1984). "Financial Intermediation and Delegated Monitoring." Review of Economic Studies 51(3):393-414. http://www. jstor. org/stable/2297430.

Diamond, Douglas W. and Philip H. Dybvig (1983). "Bank Runs, Deposit Insurance, and Liquidity." Journal of Political Economy 91(3):401-419. http : //www. j stor . org/stable/ 1837095.

ECB (2005). "The Reform of the Stability and Growth Pact." ECB Monthly Bulletin 59-73. https://www.ecb.europa.eu/pub/pdf/mobu/mb200508en.pdf.

European Parliament (2014). "Eurosystem Collateral Policy and Framework." Compilation of notes for Monetary Dialogue, November. https : //www. europarl .europa.eu/RegData/ etudes/IDAN/2014/587299/IP0L_IDA(2014)587299_EN.pdf.

FSB (2010). "Principles for Reducing Reliance on CRA Ratings." Financial Stability Board. https://www. fsb.org/wp-content/uploads/r_101027.pdf.

Gabor, Daniela and Cornel Ban (2016). "Banking on Bonds: The New Links Between States and Markets." JCMS: Journal of Common Market Studies 54(3):617-635. https: //doi.org/10.1111/jcms . 12309. 
Hannoun, Hervé (2011). "Sovereign risk in bank regulation and supervision: Where do we stand?" Financial stability institute, high-level meeting, Bank for International Settlements. https://www. bis . org/speeches/sp111026.pdf.

Issing, Otmar (2005). "One size fits all! A single monetary policy for the euro area." Speech at the International Research Forum. https://www.ecb.europa.eu/press/key/date/ 2005/html/sp050520.en.html.

Kashyap, Anil K., Raghuram Rajan, and Jeremy C. Stein (2002). "Banks as Liquidity Providers: An Explanation for the Coexistence of Lending and Deposit-Taking." Journal of Finance 57(1):33-73. https ://doi .org/10.1111/1540-6261.00415.

Lengwiler, Yvan and Athanasios Orphanides (2020). "Options for the ECB's Monetary Policy Strategy Review." Study PE 652.753, European Parliament. https://www. europarl. europa. eu/RegData/etudes/STUD/2020/652753/IPOL_STU(2020)652753_EN . pdf.

Nyborg, Kjell (2017). Collateral Frameworks: The Open Secret of Central Banks. Cambridge, Cambridge University Press.

Orphanides, Athanasios (2017). "ECB monetary policy and euro area governance: Collateral eligibility criteria for sovereign debt." In Ernest Gnan and Donato Masciandaro, eds., New Challenges in Central Banking: Monetary Policy Governance and Macroprudential Issues, 13-28. SUERF Conference Proceedings, 2017/2. https: //www. suerf . org/studies/6803/new-challenges - in - cent ral banking-monetary-policy-governance-and-macroprudential-issues.

(2020). "The Fiscal-Monetary Policy Mix in the Euro Area: Challenges at the Zero Lower Bound." Economic Policy https ://doi . org/10. 1093/epolic/eiaa017. 


\section{Appendices}

\section{A Formal derivation of result 1}

This appendix follows section 2 but, unlike in the main text, we do not simply assume that liquid assets are scarce. Instead, we will derive assumption 2 and show that it is sufficient to to make bonds scarce as a source of liquidity in equilibrium. We will also show that assumption 1 is sufficient to make the existence of a state advantageous compared to autarky, and will will furthermore show that it is always welfare-inferior to create more safe liquid bonds than what is strictly necessary for the government to function.

\section{A.1 Arbitrage condition}

The model is

$$
\begin{array}{rlr}
D & =K+B / r, & \text { (bank balance sheet) } \\
L & =(1-h) B / r, & \text { (available liquidity from repos) } \\
V & =\xi \max \{0, \lambda D-L\}, & \text { (cost of liquidity) } \\
\pi & =R K+B-D-V, & \text { (bank profit) } \\
G & =\frac{B}{r}, & \text { (public funding) } \\
Y & =R^{\prime} K, & \text { (production function) } \\
R^{\prime} & = \begin{cases}R>1 & \text { if } G \geqslant \gamma D, \\
1 & \text { otherwise, }\end{cases} \\
\tau Y & =B . & \text { (productivity of capital) }
\end{array}
$$

Substituting, the objective of the banks is

$$
\pi= \begin{cases}R\left(D-\frac{B}{r}\right)+B-D-\xi\left(\lambda D-(1-h) \frac{B}{r}\right) & \text { if } \lambda D>L \\ R\left(D-\frac{B}{r}\right)+B-D & \text { if } \lambda D<L .\end{cases}
$$

The first-order condition of the banks' problem then gives rise to an arbitrage condition

$$
r= \begin{cases}R-(1-h) \xi & \text { if } \lambda D>(1-h) B / r \\ R & \text { if } \lambda D<(1-h) B / r\end{cases}
$$


The upper branch applies when bonds are scarce as a source of collateral $(\lambda D>L)$. This is the situation discussed in the text. The lower branch applies when banks do not require loans as collateral and therefore never pay the fee $\xi$. As a result, bonds do not enjoy a liquidity premium as collateral is not scarce.

\section{A.2 Optimal provision of bonds}

The government wants to assure that the economy can function, i.e. it wants to have public finance of at least $\gamma D$. Of course, having more public finance than this minimum has the drawback that it crowds out more capital from private companies that necessary. Therefore, a natural benchmark is to assume that the government issues bonds so that the necessary size of the public finance is just met, $B / r=\gamma D$.

However, it is not guaranteed that having a functioning economy is preferrable to having individual autarky in which all households simply eat their endowment. Social welfare in the autarky economy is $D$. Social welfare in the functioning economy is output, $Y$, minus the expected resource cost of providing liquidity, i.e. the verification cost of the central bank when accepting loans as collateral, $V$. This is spelled out in (2) in the text. In addition, if taxation is distortionary, we should also subtract the desdweight loss of taxation, but we ignore this here.

It is straightforward to verify that $W>D$ if and only if $R$ is large enough, $R(1-\gamma)>$ $1+\xi(\lambda-(1-h) \gamma)$. The required $R$ that is necessary for the top branch of this equation to be valid (because $W>D$ ) is increasing in $h$, hence the requirement for the desirability of a functioning economy is more demanding the larger the haircut $h$ is. Assumption 1 guarantees that this condition is always satisfied, even if $h=1$. This implies that a welfare maximizing government wants to collect at least $\gamma D$ public funds. The alternative leads to an unintereting equilibrium in which the productivity of the private economy $R$ does not justify its existence, and in which the welfare maximizing government would optimally choose not to exists, $G=0$.

Can there be a reason that the government would want to collect more than the minimum required, $B / r>\gamma D$ ? The drawback of such a behavior is that the funds allocated to the government will be lacking as productive capital in the private firms. This crowding out will diminish total output. On the other hand, there are also costs involved with a scarcity of liquid assets. Bonds play two roles in this economy. Their primary function is to allow the government to finance public goods. Their secondary benefit is that they facilitate the acquisition of liquidity for banks. Very scarce supply of bonds destroys resources by 
forcing banks to use loans as collateral in repos and thereby facing larger transaction cost $\xi$. In other words, it is conceivable that there is a trade-off between crowding out private investment and providing assets to banks to allow them to procure liquidity more cheaply.

Let $s D \geqslant 0$ be the excess funds that the government collects from issuing $B^{\prime}>B=r \gamma D$ bonds, i.e. $s D=\left(B^{\prime}-B\right) / r$. Welfare is then

$$
W=R(1-\gamma-s) D-\xi(\lambda-(1-h)(\gamma+s)) D
$$

The derivative of $W$ wrt $s$ is

$$
\frac{\partial W}{\partial s}=(-R+\xi(1-h)) D
$$

This is likely to be negative, because $R>1,(1-h) \leqslant 1$ and $\xi$ is not extremely large. Indeed, we knwo from (1) that at $(1-h)=1$ we have $r=R-\xi$, or $R=r+\xi$. So the derivative becomes

$$
\frac{\partial W}{\partial s}=(-(r+\xi)+\xi) D=-r D<0
$$

Making $(1-h)<1$ decreases $\partial W / \partial s$ further, so that it can never become positive.

We conclude that the cost of crowding out public loans by issuing excess bonds can never be compensated by the saved transaction cost that is achieved by easing the banks' liquidity need. Bond supply is therefore given by

$$
B=r \gamma D
$$

\section{A.3 Equilibrium yields}

Putting the arbitrage condition (1) and bond supply (8) together we find the equilibrium bond yield. The equilibrium yield on government bonds is

$$
r= \begin{cases}R-(1-h) \xi & \text { if } \lambda>(1-h) \gamma, \\ \tilde{r} \in[R-(1-h) \xi, R] & \text { if } \lambda=(1-h) \gamma, \\ R & \text { if } \lambda<(1-h) \gamma .\end{cases}
$$

The first branch is the interesting case when there is indeed a liquidity premium as discussed in the main text. Assumption 2 guarantees that only the first branch of this equation is 
relevant for arbitrary $h$, which is result 1 .

\section{B Equilibrium with partial default}

The liability of the government is $B=r \gamma D$. The maximum tax receips are $\bar{\tau} Y=\bar{\tau} \tilde{R}(1-\gamma) D$. Partial default $(\delta<1)$ happens if the former exceeds the latter,

$$
\delta=\min \left\{1, \frac{\bar{\tau}(R(1-\gamma)-\tilde{s})}{r \gamma}\right\}
$$

with $r$ determined by (7),

$$
\delta=\min \left\{1, E[\tilde{\delta}] \frac{\bar{\tau}(R(1-\gamma)-\tilde{s})}{\gamma(R-(1-h) \xi)}\right\} .
$$

Define

$$
\begin{aligned}
& X:=\bar{\tau} R(1-\gamma), \\
& Y:=X-\bar{\tau} s, \\
& Z:=\gamma(R-(1-h) \xi),
\end{aligned}
$$

and let $\delta_{0}$ be the recovery rate if the crisis does not materialize, and $\delta_{1}$ is it does materialize,

$$
\delta_{0}=\max \left\{1, E[\tilde{\delta}] \frac{X}{Z}\right\}, \quad \delta_{1}=\max \left\{1, E[\tilde{\delta}] \frac{Y}{Z}\right\}
$$

and by definition,

$$
E[\tilde{\delta}]=(1-p) \delta_{0}+p \delta_{1}
$$

This is a system of two equations in two unknowns. Observe that $\delta_{1} \leqslant \delta_{0}$ by definition. To solve this, we need to distinguish three cases.

(a) $\delta_{0}=\delta_{1}=1$. In this case, $E[\tilde{\delta}]=1$. If $Y \geqslant Z$, then $\delta_{1}=1$ and therefore $\delta_{0}=1$ as well. In this case, default never occurs due to a combination of a large tax ceiling $\bar{\tau}$, large liquidity value $(1-h)$, and a not too deep crisis $s$. In this case, the simpler model of section 2 still applies and nothing is changed by the introduction of the possibility of default, because default never happens. 
$Y \geqslant Z$ amounts to

$s \leqslant \check{s}:=\frac{X-Z}{\bar{\tau}}=\frac{R \bar{\tau}(1-\gamma)-\gamma(R-(1-h) \xi)}{\bar{\tau}}$.

If the potential crisis is benign enough, default does not happen.

(b) $\delta_{1}<1=\delta_{0}$. This is the interesting case in which the government finances are sound if the crisis does not materializes, but the tax ceiling will be binding if the crisis does occur, and there will be partial default of the government in that case.

Here we have $E[\tilde{\delta}]=(1-p) \cdot 1+p \delta_{1}$. The following equations must simultaneously hold,

$$
\begin{aligned}
& E[\tilde{\delta}] \frac{X}{Z} \geqslant 1=\delta_{0}, \\
& E[\tilde{\delta}] \frac{Y}{Z}=\delta_{1}<1 .
\end{aligned}
$$

Using the definition of $E[\tilde{\delta}]$ and resolving yields

$$
\begin{aligned}
& E[\tilde{\delta}]=\frac{Z-p Z}{Z-p Y} . \\
& \delta_{1}<1 \text { requires } Y<Z \text {, or equivalently } s>\check{s} . \delta_{0} \geqslant 1 \text { requires } \\
& s \leqslant \hat{s}:=\frac{R \bar{\tau}(1-\gamma)-\gamma(R-(1-h) \xi)}{p \bar{\tau}}=\frac{\check{s}}{p} .
\end{aligned}
$$

For $\check{s}<s \leqslant \hat{s}$, case (b) applies, so the crisis must be grave enough $(s>\check{s}$ ), but not too grave $(s \leqslant \hat{s})$. If it is too grave, we enter case (c) below.

Note that $\check{s}$ and $\hat{s}$ increase with $\bar{\tau}$, implying that fiscally less performant governments ( $\bar{\tau}$ is smaller) are more vulnerable to even smaller crises. Moreover, the two thresholds also decrease with $h$, implying that a larger $h$ increases vulnerability of government finance to crises.

(c) $\delta_{1} \leqslant \delta_{0}<1$. This is the situation where the government's finance is not perfectly safe, even if the crisis does not materialize. The government will not be able to fully repay the bonds in any case. $\delta_{0}<1$ is equivalent to $\hat{s}<s$. 
We have $E[\tilde{\delta}]=(1-p) \delta_{0}+p \delta_{1}$, with

$$
\begin{aligned}
& E[\tilde{\delta}] \frac{X}{Z}=\delta_{0}<1, \\
& E[\tilde{\delta}] \frac{Y}{Z}=\delta_{1}<\delta_{0}
\end{aligned}
$$

This implies

$$
\overbrace{\left[\begin{array}{cc}
(1-p) X-Z & p X \\
(1-p) Y & p Y-Z
\end{array}\right]}^{M}\left[\begin{array}{c}
\delta_{0} \\
\delta_{1}
\end{array}\right]=\left[\begin{array}{l}
0 \\
0
\end{array}\right] .
$$

$M$ has full rank unless $s=\hat{s}$. Thus, for $s>\hat{s}$, the only solution is $\delta_{0}=\delta_{1}=0$. The equilibrium with a government breaks down. Only autarky is possible.

(d) $E[\tilde{\delta}]$ and the derivatives wrt $h$ in case (b). Inspection of (10) reveals that $\partial E[\tilde{\delta}] / \partial \bar{\tau}>$ 0 and $\partial E[\tilde{\delta}] / \partial h<0$, as claimed in the main text. The expected recovery rate is smaller the less performant tax collection is (smaller $\bar{\tau}$ ), and the more restrictive the collateral framework of the central bank is (larger $h$ ). 


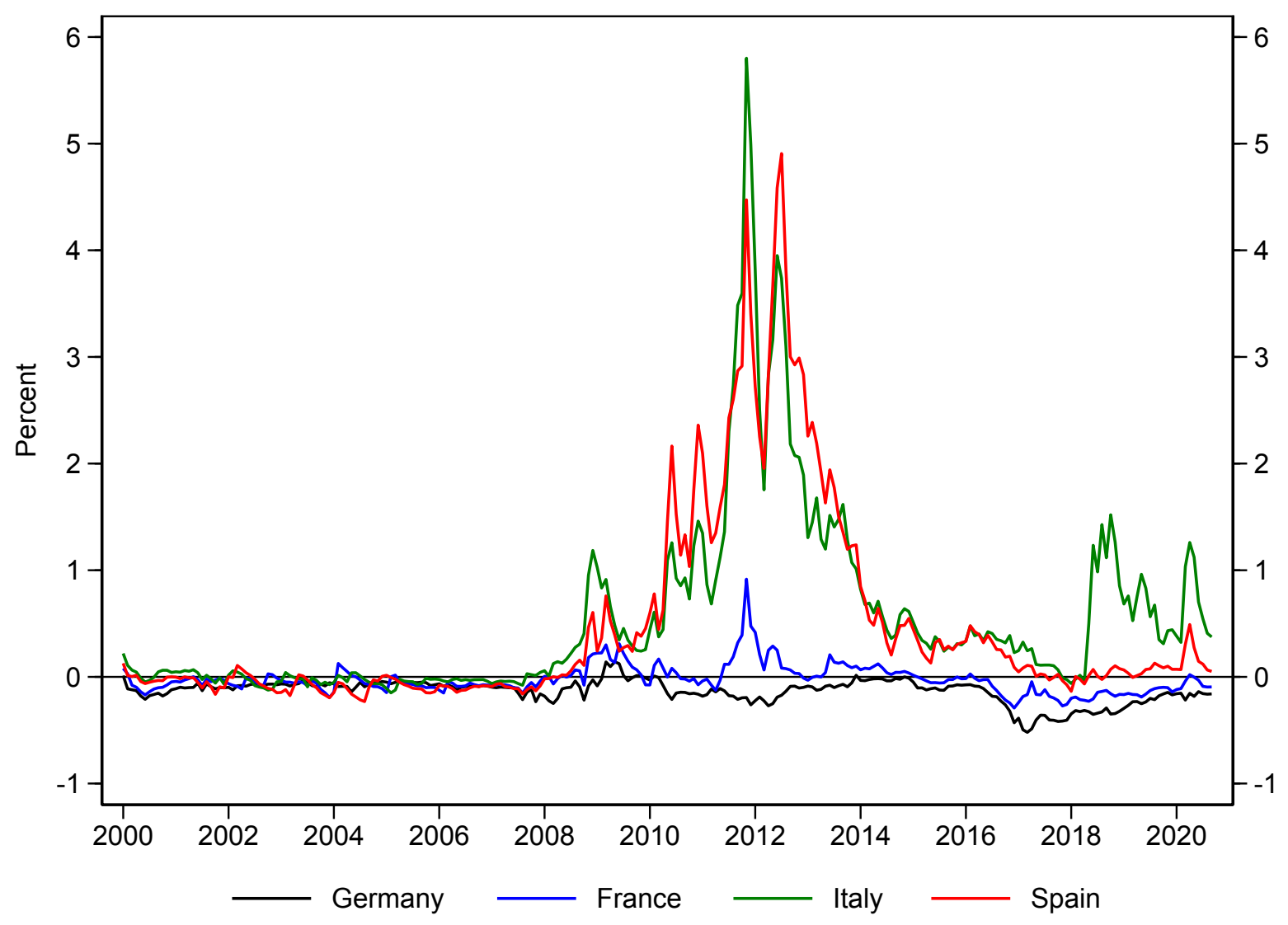

Figure 1: What is the "fundamental spread?" (Notes: Spread between 2-year sovereign bond yield and OIS rate.) 


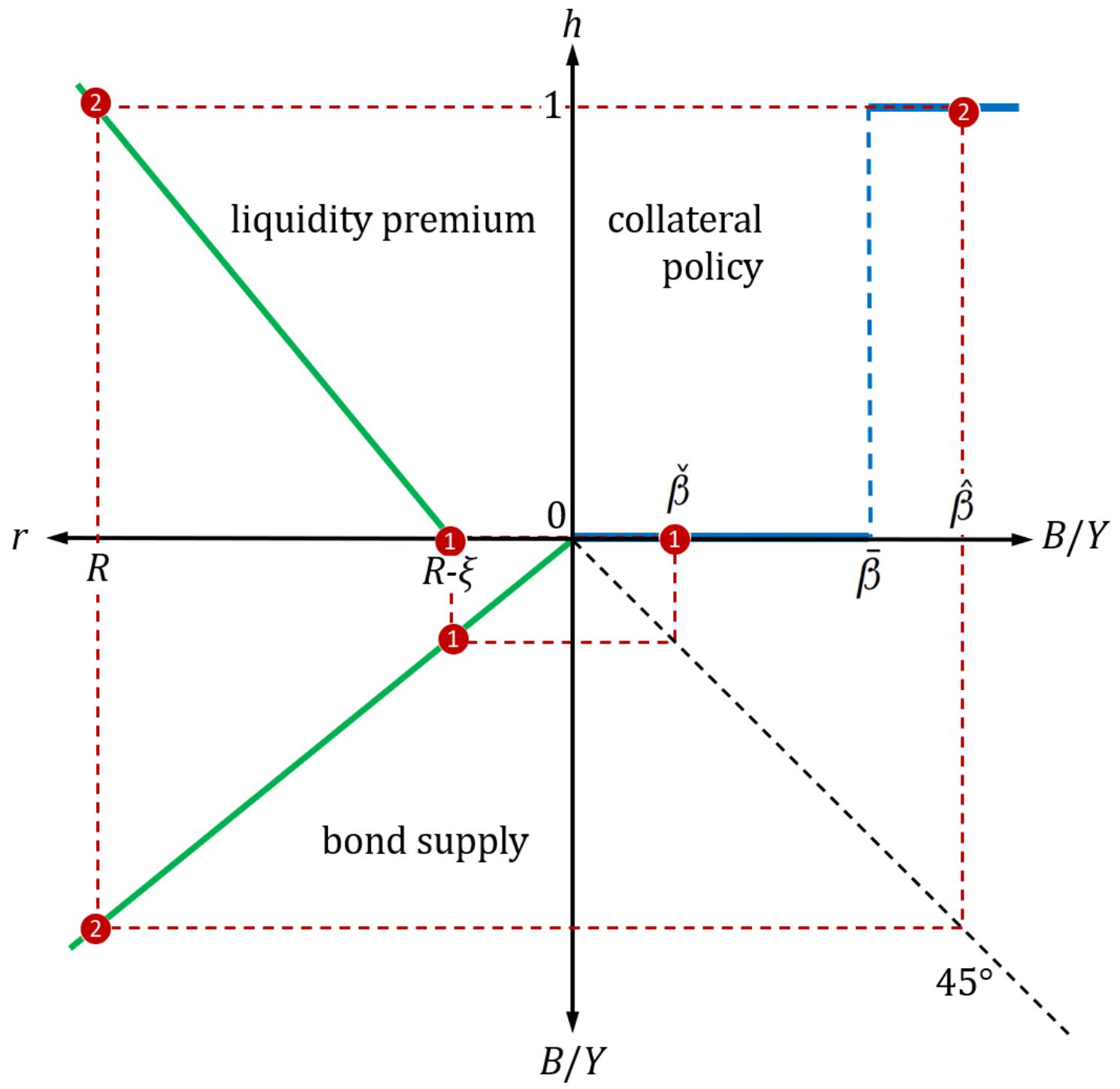

Figure 2: Multiple equilibria. (Notes: As described by result 2. (1) is the good, (2) the bad equilibrium.) 


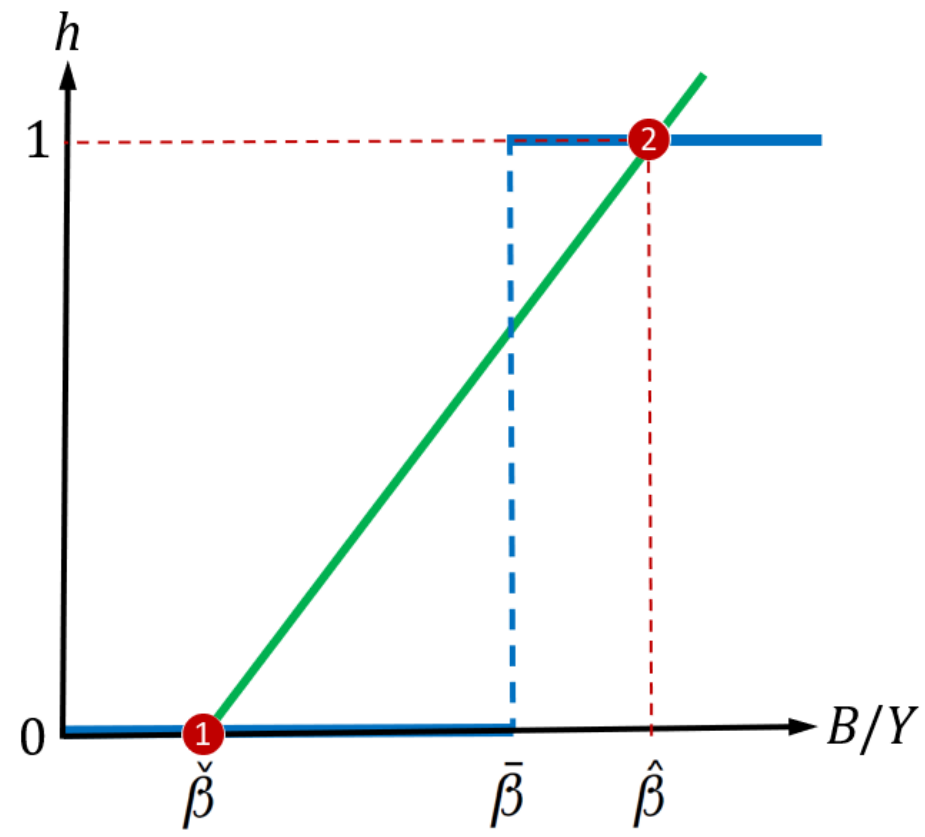

Figure 3: Multiple equilibria with cliff effect.

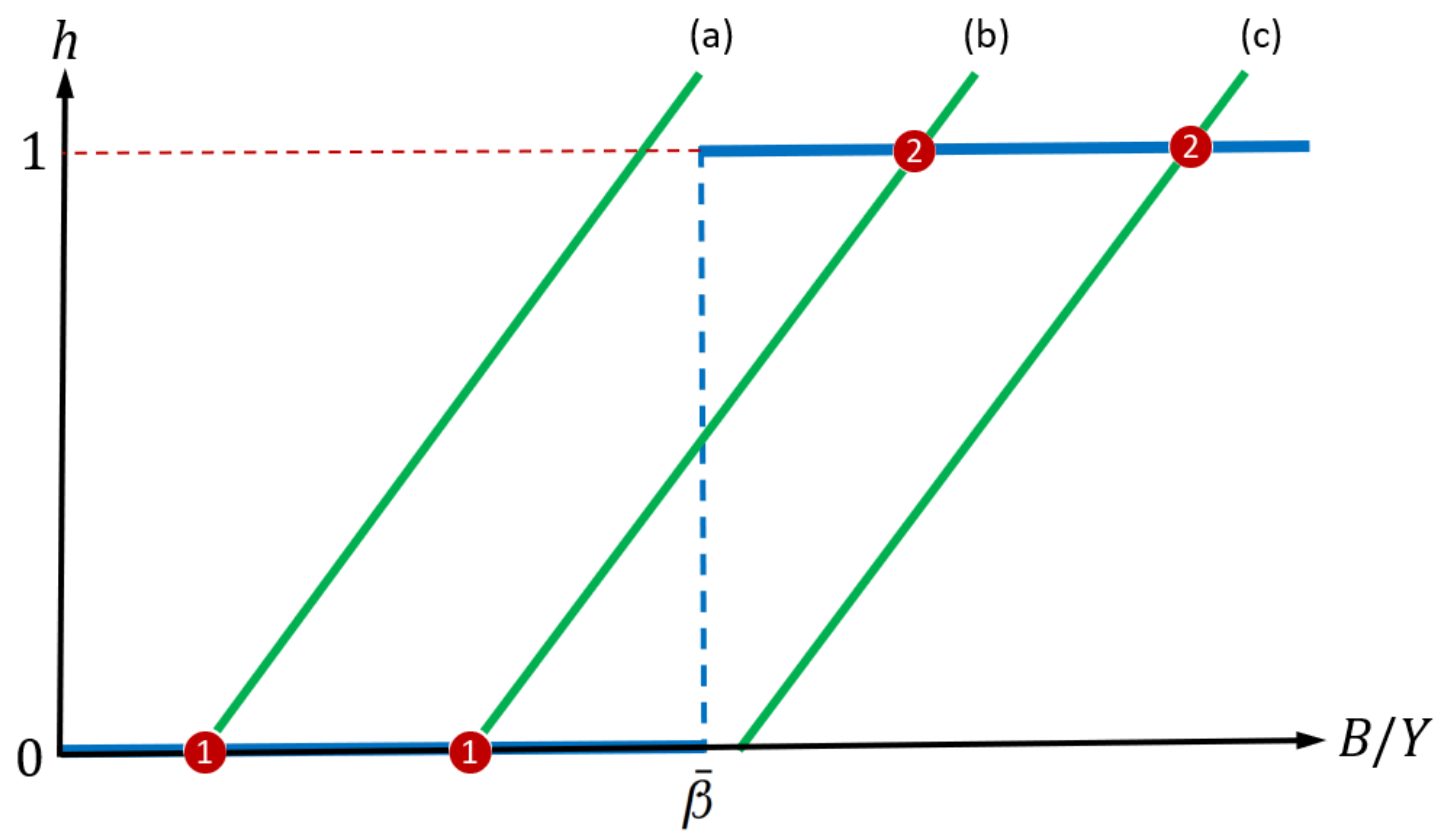

Figure 4: Multiple equilibria with pre-existing debt. 


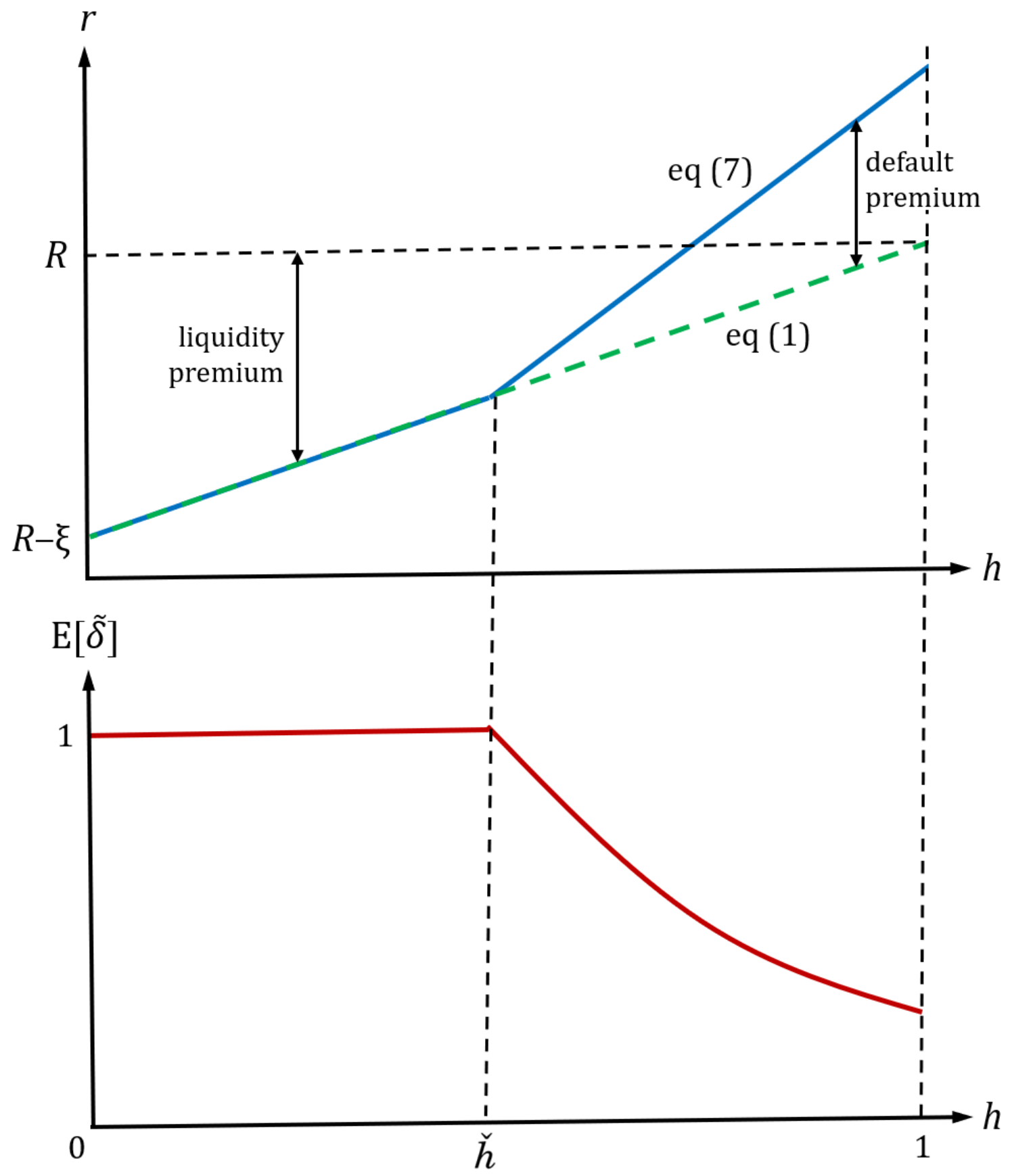

Figure 5: Liquidity premium, default premium, and expected recovery rate as functions of $h$. (Note: $\breve{h}$ is the haircut where $\check{s}$ of result 3 equals the exogenously given depth of the probabilistic crisis $s$.) 


\section{IMFS WORKING PAPER SERIES}

\section{Recent Issues}

\begin{tabular}{|c|c|c|}
\hline $156 / 2021$ & $\begin{array}{l}\text { Gregor Boehl } \\
\text { Cars Hommes }\end{array}$ & $\begin{array}{l}\text { Rational vs. Irrational Beliefs in a Complex } \\
\text { World }\end{array}$ \\
\hline 155 / 2021 & $\begin{array}{l}\text { Michael D. Bauer } \\
\text { Eric T. Swanson }\end{array}$ & $\begin{array}{l}\text { The Fed's Response to Economic News } \\
\text { Explains the "Fed Information Effect" }\end{array}$ \\
\hline $154 / 2021$ & Alexander Meyer-Gohde & $\begin{array}{l}\text { On the Accuracy of Linear DSGE Solution } \\
\text { Methods and the Consequences for Log- } \\
\text { Normal Asset Pricing }\end{array}$ \\
\hline $153 / 2021$ & $\begin{array}{l}\text { Gregor Boehl } \\
\text { Philipp Lieberknecht }\end{array}$ & $\begin{array}{l}\text { The Hockey Stick Phillips Curve and the } \\
\text { Zero Lower Bound }\end{array}$ \\
\hline $152 / 2021$ & $\begin{array}{l}\text { Lazar Milivojevic } \\
\text { Balint Tatar }\end{array}$ & $\begin{array}{l}\text { Fixed exchange rate - a friend or foe of } \\
\text { labor cost adjustments? }\end{array}$ \\
\hline $151 / 2021$ & $\begin{array}{l}\text { Thomas Jost } \\
\text { Franz Seitz }\end{array}$ & $\begin{array}{l}\text { Designing a European Monetary Fund: } \\
\text { What role for the IMF? }\end{array}$ \\
\hline $150 / 2021$ & $\begin{array}{l}\text { Gerhard Rösl } \\
\text { Franz Seitz }\end{array}$ & $\begin{array}{l}\text { Cash and Crises: No surprises by the } \\
\text { virus }\end{array}$ \\
\hline 149 / 2021 & $\begin{array}{l}\text { Wolfgang Lechthaler } \\
\text { Mewael F. Tesfaselassie }\end{array}$ & $\begin{array}{l}\text { Endogenous Growth, Skill Obsolescence } \\
\text { and Output Hysteresis in a New } \\
\text { Keynesian Model with Unemployment }\end{array}$ \\
\hline $148 / 2021$ & Gregor Boehl & $\begin{array}{l}\text { Efficient Solution and Computation of } \\
\text { Models with Occasionally Binding } \\
\text { Constraints }\end{array}$ \\
\hline $147 / 2021$ & $\begin{array}{l}\text { Brian Fabo } \\
\text { Martina Jančoková } \\
\text { Elisabeth Kempf } \\
\text { Luboš Pástor }\end{array}$ & $\begin{array}{l}\text { Fifty Shades of QE: Conflicts of Interest in } \\
\text { Economic Research }\end{array}$ \\
\hline $146 / 2021$ & $\begin{array}{l}\text { Robert C.M. Beyer } \\
\text { Lazar Milivojevic }\end{array}$ & $\begin{array}{l}\text { Dynamics and Synchronization of Global } \\
\text { Equilibrium Interest Rates }\end{array}$ \\
\hline $145 / 2020$ & $\begin{array}{l}\text { Lars P. Feld } \\
\text { Volker Wieland }\end{array}$ & $\begin{array}{l}\text { The German Federal Constitutional Court } \\
\text { Ruling and the European Central Bank's } \\
\text { Strategy }\end{array}$ \\
\hline $144 / 2020$ & $\begin{array}{l}\text { Mátyás Farkas } \\
\text { Balint Tatar }\end{array}$ & $\begin{array}{l}\text { Bayesian Estimation of DSGE Models } \\
\text { with Hamiltonian Monte Carlo }\end{array}$ \\
\hline $143 / 2020$ & $\begin{array}{l}\text { Gregor Boehl } \\
\text { Felix Strobel }\end{array}$ & $\begin{array}{l}\text { U.S. Business Cycle Dynamics at the } \\
\text { Zero Lower Bound }\end{array}$ \\
\hline $142 / 2020$ & $\begin{array}{l}\text { Gregor Boehl } \\
\text { Gavin Goy } \\
\text { Felix Strobel }\end{array}$ & $\begin{array}{l}\text { A Structural Investigation of Quantitative } \\
\text { Easing }\end{array}$ \\
\hline
\end{tabular}




\begin{tabular}{|c|c|c|}
\hline $141 / 2020$ & Karl-Heinz Tödter & $\begin{array}{l}\text { Ein SIRD-Modell zur Infektionsdynamik } \\
\text { mit endogener Behandlungskapazität und } \\
\text { Lehren für Corona-Statistiken }\end{array}$ \\
\hline $140 / 2020$ & $\begin{array}{l}\text { Helmut Siekmann } \\
\text { Volker Wieland }\end{array}$ & $\begin{array}{l}\text { The Ruling of the Federal Constitutional } \\
\text { Court concerning the Public Sector } \\
\text { Purchase Program: A Practical Way } \\
\text { Forward }\end{array}$ \\
\hline $139 / 2020$ & Volker Wieland & $\begin{array}{l}\text { Verfahren zum Anleihekaufprogramm der } \\
\text { EZB }\end{array}$ \\
\hline $138 / 2020$ & $\begin{array}{l}\text { Francisco Gomes } \\
\text { Michael Haliassos } \\
\text { Tarun Ramadorai }\end{array}$ & Household Finance \\
\hline $137 / 2019$ & $\begin{array}{l}\text { Martin Kliem } \\
\text { Alexander Meyer-Gohde }\end{array}$ & $\begin{array}{l}\text { (Un)expected Monetary Policy Shocks } \\
\text { and Term Premia }\end{array}$ \\
\hline $136 / 2019$ & $\begin{array}{l}\text { Luc Arrondel } \\
\text { Hector Calvo-Pardo } \\
\text { Chryssi Giannitsarou } \\
\text { Michael Haliassos }\end{array}$ & Informative Social Interactions \\
\hline $135 / 2019$ & $\begin{array}{l}\text { Tiziana Assenza } \\
\text { Alberto Cardaci } \\
\text { Domenico Delli Gatti }\end{array}$ & $\begin{array}{l}\text { Perceived wealth, cognitive sophistication } \\
\text { and behavioral inattention }\end{array}$ \\
\hline $134 / 2019$ & Helmut Siekmann & $\begin{array}{l}\text { The Asset Purchase Programmes of the } \\
\text { ESCB - an interdisciplinary evaluation }\end{array}$ \\
\hline $133 / 2019$ & $\begin{array}{l}\text { Josefine Quast } \\
\text { Maik Wolters }\end{array}$ & $\begin{array}{l}\text { Reliable Real-time Output Gap Estimates } \\
\text { Based on a Modified Hamilton Filter }\end{array}$ \\
\hline $132 / 2019$ & $\begin{array}{l}\text { Galina Potjagailo } \\
\text { Maik Wolters }\end{array}$ & Global Financial Cycles since 1880 \\
\hline $131 / 2019$ & $\begin{array}{l}\text { Philipp Lieberknecht } \\
\text { Volker Wieland }\end{array}$ & $\begin{array}{l}\text { On the Macroeconomic and Fiscal Effects } \\
\text { of the Tax Cuts and Jobs Act }\end{array}$ \\
\hline $130 / 2019$ & Eduard Hofert & Regulating Virtual Currencies \\
\hline $129 / 2018$ & $\begin{array}{l}\text { Olga Goldfayn-Frank } \\
\text { Johannes Wohlfart }\end{array}$ & $\begin{array}{l}\text { How Do Consumers Adapt to a New } \\
\text { Environment in their Economic } \\
\text { Forecasting? Evidence from the German } \\
\text { Reunification }\end{array}$ \\
\hline $128 / 2018$ & $\begin{array}{l}\text { Christopher Roth } \\
\text { Johannes Wohlfart }\end{array}$ & $\begin{array}{l}\text { How Do Expectations About the } \\
\text { Macroeconomy Affect Personal } \\
\text { Expectations and Behavior? }\end{array}$ \\
\hline $127 / 2018$ & $\begin{array}{l}\text { Michael Haliassos } \\
\text { Thomas Jansson } \\
\text { Yigitcan Karabulut }\end{array}$ & Financial Literacy Externalities \\
\hline $126 / 2018$ & Felix Strobel & $\begin{array}{l}\text { The Government Spending Multiplier, } \\
\text { Fiscal Stress and the Zero Lower Bound }\end{array}$ \\
\hline
\end{tabular}

